\title{
Product Characteristics and Shelf-Life Effect of Low-Fat Functional Sausages Manufactured with Sodium Lactate and Chitosans During Storage at $10^{\circ} \mathrm{C}$
}

\author{
Soon Hee Choi and Koo Bok Chin* \\ Department of Animal Science and Biotechnology Research Institute, Chonnam National University, \\ Gwangju 500-600, Korea
}

\section{젖산나트륨과 다양한 분자량의 키토산을 함유한 저지방 소시지의 $10^{\circ} \mathrm{C}$ 에서 냉장저장 중 품질과 저장성 효과}

\author{
최순희 · 진구복* \\ 전남대학교 동물자원학부 및 생물공학연구소
}

\begin{abstract}
Product quality and shelf-life effect of sodium lactate (SL) in combined with chitosans with various molecular weights (MW) in low-fat sausages (LFSs) stored at $10^{\circ} \mathrm{C}$ were evaluated. LFSs with SL and chitosans had 75-76\% moisture, $1-2 \%$ fat, and 15.8-17.1\% protein with a $\mathrm{pH}$ range of 6.3-6.6. Water holding capacity was decreased, but most textural properties were increased with the addition of chitosan with MW of 30-40 kDa. Hunter a (redness) values were also increased with the addition of sodium lactate and chitosans in combination with laccaic acid at the level of $0.05 \%$, resulting in similar Hunter a value of $150 \mathrm{ppm}$ of sodium nitrite. The combination of SL and chitosans slightly extended the shelf-life of LFSs approximately 3-6 days at $10^{\circ} \mathrm{C}$, resulting in inhibition the growth of L. monocytogenes and E. coli $\mathrm{O} 157: \mathrm{H} 7$, as compared to the control. However, the inhibition of microbial growth at $10^{\circ} \mathrm{C}$ was not as strong as that at $4^{\circ} \mathrm{C}$. Thus, the storage temperature should be as low $\left(<4^{\circ} \mathrm{C}\right)$ as possible to have a maximum antimicrobial activity in LFS containing SL and various chitosans.
\end{abstract}

Key words : low-fat sausages, sodium lactate, chitosan, laccaic aicd, shelf-life

\section{Introduction}

Emulsified-sausages manufactured in Korea may contain up to 30-35\% fat, an important ingredient for the production of desirable flavor and texture in processed meats (Chin et al., 2006). Additionally, fat plays an important role in the contribution of textural properties, rich flavor, and sensory characteristics in comminuted sausages (Matulis et al., 1995a; Matulis et al. 1995b). However, excess fat consumption in the diet has been associated with increases in the incidence of coronary heart disease, obesity, and other related diseases (AHA, 1978). Thus,

*Corresponding author : Koo Bok Chin, Department of Animal Science, Chonnam National University, Gwangju 500-757, Korea. Tel: 82-62-530-2121, Fax: 82-62-530-2129, E-mail: kbchin@chonnam.ac.kr consumer's food selections have recently focused on lowfat and low-salt types of foods. As a result, the demand for low-fat, and low-salt meat products has been increased to meet the consumer's need.

However, low-fat meat products (LFMP) have problems related to low-flavor and textural characteristics, and variations in products (Keeton, 1994). They also had shorter shelf-life than regular-fat counterparts due to the high moisture content. To improve the product quality of low-fat sausages (LFSs), several studies have been performed. The combination of sodium lactate (SL) and a fat replacer improved the quality of products and extend shelf-life of very low-fat bologna (Chin and Choi, 2001). The triple addition of konjac flour, carrageenan, and soy protein isolate at the ratio of 1:1:3 improved functional and textural properties that imitated those of regular-fat sausages, as compared to single or double additions (Choi 
and Chin, 2002). LFS (<2\% fat) containing at least 3.3\% SL solution $(60 \%)$ and a fat replacer had a greater antilisterial effect than the low-fat control (Murano et al., 1995; Bloukas et al., 1997; Lin and Lin, 2002; Choi et al., 2003).

Since meat products contained chemical curing agents and preservatives, such as potassium sorbate and sodium nitrite, some consumers tended to avoid the consumption of meat products. Thus, natural ingredients could be replaced with these chemical ingredients to meet the consumer demands (Choi and Chin, 2003).

Chitosan is a polysaccharide found in the shells of crabs and shrimp. Since it has antimicrobial, antioxidant, and antitumor activity, it has been widely used in the food industry. Chitosan with molecular weight (MW) of 120 $\mathrm{kDa}$ has been studied to extend shelf-life in emulsifiedsausage by increased antimicrobial activity and reduced the level of sodium nitrite as a curing agent (Park et al., 1999). Youn et al. (2000) suggested that $120 \mathrm{kDa}$ chitosan $(0.2 \%)$ inhibited over $80 \%$ growth against the pathogens tested, and antibacterial activity in emulsifiedsausage increased with MW. Lin and Chao (2001) reported that the addition of chitosan with MW ranging from 150 to $1,250 \mathrm{kDa}$ did not adversely affect the textural and sensory traits of reduced-fat Chinese-style sausage. Jo et al. (2001a) reported that the addition of chitosan oligomer (MW=1,000 Da and 5,000 Da) on emulsion-type sausage did not inhibit the growth of pathogens. Roller et al. (2002) found a preservative system for fresh pork sausages based on the combination of chitosan, carnocin, and a low-concentration of sulphite. The combination of chitosan and sulphite was acceptable for a longer period than other batches. Kook et al. (2003) reported that the combination of SL (2\%) and various levels of chitosan in water-boiled LFSs inhibited the microbial growth of Listeria monocytogenes during refrigerated storage, and $0.5 \%$ lac pigment (laccaic acid) which is obtained from the secretion of an Indian insect (Coccus laccae), and has been used to improve the color of cured meat products when sodium nitrite has been replaced, was used to replace sodium nitrite at 75 to $150 \mathrm{ppm}$. Thus, the objective of this study was to determine the product quality and antimicrobial activity of SL in combined with various MW of chitosans in LFSs stored at $10^{\circ} \mathrm{C}$.

\section{Materials and Methods}

\section{Low-fat sausage manufacture}

This procedure of low-fat sausage manufacture was fol- lowed by our previous report (Chin and Choi, 2005). Fresh pork hams and pork backfats were purchased from a local meat market. The formulation of non-meat ingredients, and processing procedures of regular-fat control (RFC) and low-fat sausages (LFS) were performed according to previous procedures reported by Chin et al. (2004), and Chin and Choi (2005). After the manufacture of the LFSs, physicochemical and textural properties, and microbial changes of inoculated pathogens were measured during storage at $10^{\circ} \mathrm{C}$.

\section{Inoculation of pathogens in the sausages}

The inoculation of two pathogens in the sausages was according to the previous report by Choi et al. (2003). Listeria monocytogenes strain (LM, ATCC, 43256), Salmonella typhimurium LT2 strain (ATCC 19585), and $E$ coli 0157:H7 were cultured on tryptic soy agar (TSA) and incubated at $37^{\circ} \mathrm{C}$ for $48 \mathrm{hr}$. The TSA-grown colonies were harvested in $5 \mathrm{~mL}$ of tryptic soy broth and incubated in a shaking water bath at $37^{\circ} \mathrm{C}$ for about $19 \mathrm{hr}$. After the cellulose casings were peeled off, the fully grown bacterial suspension (approximately $10^{9} \mathrm{CFU} / \mathrm{mL}$ ) was diluted with sterilized double-distilled (dd)-water to a final concentration of $10^{5} \mathrm{CFU} / \mathrm{mL}$. One $\mathrm{mL}$ of bacterial suspension was surface inoculated and mixed with each $25 \mathrm{~g}$ of sausage samples. Sausages were then vacuum-packaged (TAEVAC 600MX, Yoiwang-city, Kyungki-do, Korea) using cryovac-extruded film (7325B, Sealed Air Korea Inc, Seoul, Korea) at $-20 \mathrm{mmHg}$ and stored at $10^{\circ} \mathrm{C}$ until analyzed at $0,1,2,4,6$, and 8 wks of storage.

\section{Proximate analysis and $\mathrm{pH}$}

Moisture, fat, and protein contents (\%) of low-fat sausages were determined using the AOAC (1995) procedure. The $\mathrm{pH}$ was measured using digital $\mathrm{pH}$ meter (Model 340, Mettler-Toledo, Schwarzenbach, Switzerland).

\section{Expressible moisture (\%)}

Water-holding capacity (WHC) was determined if the added ingredients affected the protein-moisture binding capacity and measured by a modified procedure of the centrifugal separator method (Jauregui et al., 1981). Approximately $1.5 \mathrm{~g}$ of sausage samples was wrapped with three pieces of filter paper (Whatmann, No 3) and centrifuged at $1,000 \times \mathrm{g}$ for $20 \mathrm{~min}$. Expressible moisture (EM, \% was calculated as the weight difference between the total sample and filter paper weight containing the moisture released from the sample during centrifugation. 


\section{Hunter color values ( $\mathrm{L}, \mathrm{a}, \mathrm{b})$}

The added ingredients, such as sodium lactate, chitosans and laccaic acid, may affect the color values of lowsat sausages. Thus, Hunter L, a, and b values were measured at three different locations of sausage core and surface using a Color Reader (CR-10, Minolta Co., Ltd., Japan). Data presented are means of three measurements of each sausage sample and expressed as Hunter L (brightness), a (redness) and b (yellowness) values.

\section{Texture profile analysis}

The textural measurements were performed according to the modified method of Bourne (1978). The sausage samples cut into cylinder form $(1.3 \mathrm{~cm}$ thick, $1 \mathrm{~cm}$ diameter) and measured with a texture meter (TA-XT2, Stable micro system, Hasemers, England), which was set to compress $75 \%$ of sample weight through a two-cycle compression. The sausage samples laid on a flat plate equipped with a 5-kg load cell were measured at a rate of 120 $\mathrm{mm} / \mathrm{min}$ and the following textural properties were determined: fracturability $(\mathrm{g})$, hardness $(\mathrm{g})$, springiness $(\mathrm{cm})$, chewiness, gumminess, and cohesiveness.

\section{Statistical analysis}

Data were analyzed by two-way analysis of variance (ANOVA) using the general linear models procedure of SAS (1989). A 3 (MWs of chitosans) multiplying by 6 (storage times) factorial arrangement with three replicates was performed. The interaction between SL in combined with various MW of chitosans and storage time was also tested. If interactions between main effects were significant $(p<0.05)$, data were separated by SL and chitosan combinations and storage time. If interactions were not observed between the two factors, Duncan's multiple range tests were performed to analyze the differences of parameters among the treatments.

\section{Results and Discussion}

Since no interactions were observed between the combination of sodium lactate (SL) and various MWs of chitosan, and storage time $(p>0.05)$, data were pooled by treatment or storage time.

\section{Proximate composition, $\mathrm{pH}$, and expressible mois- ture $(\%)$}

Moisture, fat and protein contents (\%) of LFSs containing SL and various MW of chitosans stored at $10^{\circ} \mathrm{C}$ are shown in Table 1. Moisture, fat, and protein contents (\%) were 74.6 to $76.0,1$ to 2 , and 15.8 to $17.1 \%$, respectively. As previously reported (Chin and Choi, 2005), proximate composition was not affected by the SL and chitosan combinations, either (Table 1). $\mathrm{pH}$ of all of the sausages was around $\mathrm{pH}$ 6.3-6.5 and was also unaffected by the SL and chitosan combinations. These $\mathrm{pH}$ ranges were similar to those of previous studies of chitosan applications in meat products (Lin and Choa, 2001; Jo et al., 2001b; Sagoo et al., 2002). Since chitosans used in this study were water soluble, no acid solvent was required to dissolve them. Lin and Choa (2001) reported that chitosans of varied $\mathrm{MW}$ were dissolved in $1 \%$ lactic acid, resulting in the lower $\mathrm{pH}$, as compared to the other studies. They suggested that the lower water retaining index (WRI) values were observed in the sausages containing chitosans due to the shift to lower $\mathrm{pH}$. The addition of SL and medium MW of chitosan tended to increase expressible moisture. The changes of expressible moisture with the addition of chitosan were not fully understood, however these results were agreed with the previous reports (Kook et al., 2003; Chin and Wang, 2004). Future study will be performed how the medium MW(30-40 kDa) of chitosan affect the water holding capacity of LFSs. Compared to our previous study(Chin and Choi, 2005), $\mathrm{pH}$ and proxi-

Table 1. Proximate composition, $\mathrm{pH}$ and expressible moisture of low-fat functional sausages

\begin{tabular}{|c|c|c|c|c|c|}
\hline \multirow{2}{*}{ Treatments } & \multicolumn{3}{|c|}{ Proximate analysis $(\%)$} & \multirow{2}{*}{$\mathrm{pH}$} & \multirow{2}{*}{$\mathrm{EM}^{4)}$} \\
\hline & Moisture & Fat & Protein & & \\
\hline Nitrite $(0 \mathrm{ppm})$ & $75.9 \pm 3.25$ & $1.21 \pm 0.37$ & $16.8 \pm 1.35$ & $6.36 \pm 0.18$ & $31.0 \pm 2.61^{\mathrm{ab}}$ \\
\hline Nitrite (150 ppm) & $76.0 \pm 3.25$ & $1.55 \pm 0.63$ & $15.8 \pm 0.75$ & $6.40 \pm 0.16$ & $26.3 \pm 3.20^{\mathrm{b}}$ \\
\hline Sodium lactate (SL) & $74.6 \pm 3.18$ & $1.18 \pm 0.36$ & $16.9 \pm 1.17$ & $6.43 \pm 0.15$ & $25.8 \pm 1.06^{\mathrm{b}}$ \\
\hline $\mathrm{SL}^{1)}+$ Chitosan $(\mathrm{L})^{2)}+\mathrm{LA}^{3)}$ & $75.1 \pm 2.19$ & $1.93 \pm 0.11$ & $17.1 \pm 1.23$ & $6.42 \pm 0.21$ & $25.6 \pm 0.42^{b}$ \\
\hline $\mathrm{SL}+$ Chitosan $(\mathrm{M})+\mathrm{LA}$ & $75.3 \pm 1.91$ & $1.61 \pm 0.04$ & $17.1 \pm 0.97$ & $6.34 \pm 0.21$ & $35.9 \pm 4.92^{\mathrm{a}}$ \\
\hline $\mathrm{SL}+$ Chitosan $(\mathrm{H})+\mathrm{LA}$ & $75.8 \pm 1.70$ & $1.56 \pm 0.18$ & $17.0 \pm 1.31$ & $6.34 \pm 0.20$ & $31.4 \pm 3.10^{\mathrm{ab}}$ \\
\hline
\end{tabular}

\footnotetext{
${ }^{1)} \mathrm{SL}$, sodium lactate.

${ }^{2)}$ Chitosan: L, low molecular weight (1.5 kDa); M, Medium (20-30 kDa); H,High ( 300 kDa).

${ }^{3)}$ LA, laccaic acid.

4) EM, Expressible moisture (\%).
} 


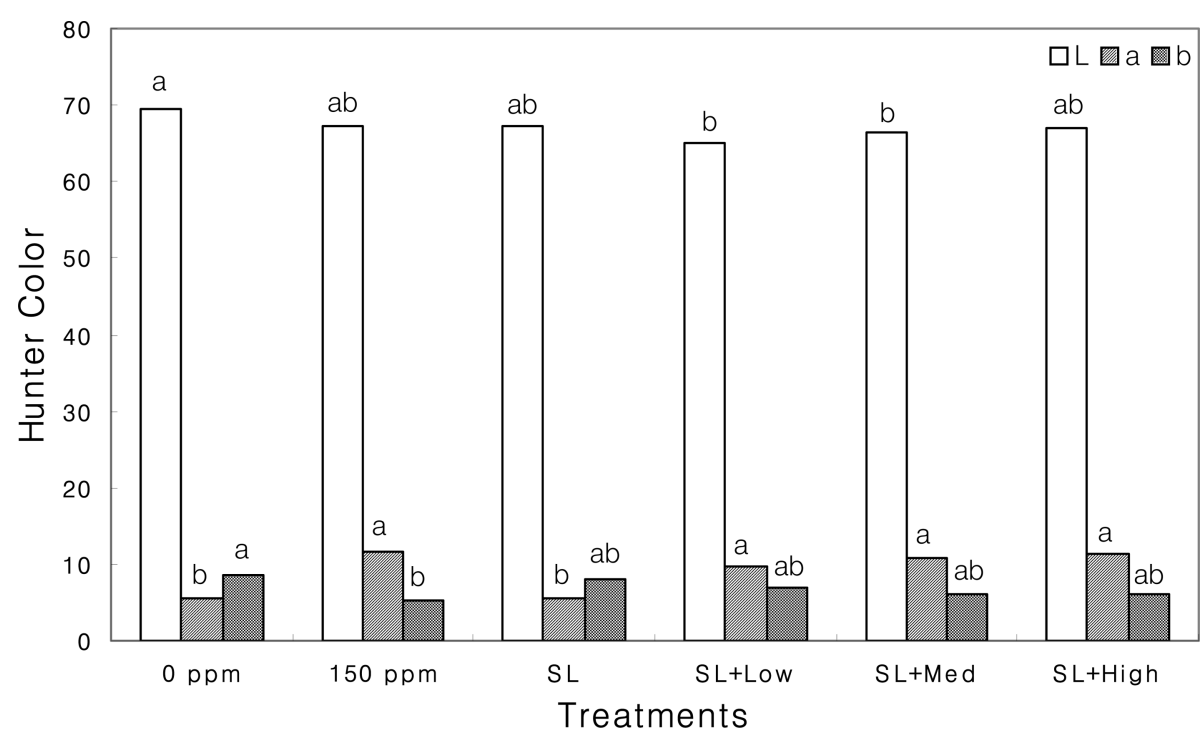

Fig. 1. Hunter color values of low-fat functional sausages manufactured with sodium lactate and various molecular weights of chitosans. L, lightness; a, redness; b, yellowness. SL, sodium lactate; Low, low molecular weight of chitosan (Low=1.5 kDa); Med, medium molecular weight of chitosan (Medium=30-40 kDa); High, high molecular weight of chitosan $(\mathrm{High}=200 \mathrm{kDa})$. ${ }^{a, b}$ Mean with same row having same superscript are not different $(p>0.05)$.

mate composition were not affected by the storage temperatures $\left(4\right.$ vs $\left.10^{\circ} \mathrm{C}\right)$.

\section{Hunter color values}

Hunter L, a, and $b$ values of LFSs with the addition of SL and various MW of chitosans are shown in Fig. 1. The addition of $0.05 \%$ Lac pigment (laccaic acid) reduced the Hunter L, but increased the Hunter a values, which resulted in increased redness values similar to those of 150 ppm of sodium nitrite in LFS. These results were supported by the previous studies (Jo et al., 2001a) which determined that LFSs containing chitosan with low or medium MWs had lower $\mathrm{L}$ values than the control. Thus, lac pigment may significantly affect the Hunter $\mathrm{L}$ and a values. Hunter b values (yellowness) of LFSs containing SL and various MW of chitosans were similar to those of $150 \mathrm{ppm}$ of sodium nitrite. In our previous report, the addition of chitosan did not improve the development of cured meat color and these results were not in agreement with the results of Park et al. (1999), who reported that chitosan stabilized the color and improved the redness values in emulsified-sausage during storage. These results were also supported by the previous study of Lin and Choa (2001), who reported that Chinese-style sausages containing chitosans had lower redness values than those of control. Thus, we have used $0.05 \%$ natural Lac pigment to replace $150 \mathrm{ppm}$ of sodium nitrite in LFSs. In other studies, cured meat color was found using by irradiation with a dose of $5 \mathrm{kGy}$, which was effective as the use of
$200 \mathrm{ppm}$ of sodium nitrite to maintain a desirable color of the ham product for 30 days (Jo et al., 2001b; Byun, et al., 1999). Since the use of sodium nitrite in meat products appears to have antimicrobial effects, and cured meat coloring has been still argued by a Korean consumer association, new natural curing agents with similar coloring properties of sodium nitrite should be found.

\section{Texture profile analysis (TPA)}

Texture properties of LFSs as affected by the addition of SL and various MW of chitosans are shown in Table 2. LFSs containing medium MW of chitosan were harder, springier and more cohesive than those with controls and low MW of chitosans $(1.5 \mathrm{kDa})(p<0.05)$. Lin and Choa (2001) reported that sausage springiness was lower in sausages with MW of 1,250 kDa of chitosans than those with MW of $600 \mathrm{kDa}$ of chitosans. However, no other textural differences were observed in the sausages, regardless of the MW of chitosans. These results were supported by the previous study in that water-boiled LFSs containing medium MW (30-40 kDa) of chitosans were harder, springier, and chewier than those of low MW (Kook et al., 2003). Chin and Wang (2004) reported that most textural characteristics were higher in LFSs containing $0.3 \%$ chitosan (30-50 kDa), as compared to the control. Based on these results, chitosan with MW medium range $(30-40 \mathrm{kDa})$ may significantly affect the textural characteristics of LFSs. The increased textural characteristics of LFSs with MW of 30-40 kDa may partially due to 
Table 2. Textural characteristics of low-fat functional sausages as affected by sodium lactate and various molecular weights of chitosans

\begin{tabular}{|c|c|c|c|c|c|c|}
\hline \multirow{2}{*}{$\mathrm{Pa}^{1)}$} & \multicolumn{2}{|c|}{ Nitrite (ppm) } & \multirow{2}{*}{$\begin{array}{l}\text { SL } \\
2 \%\end{array}$} & \multicolumn{3}{|c|}{ Chitosan } \\
\hline & 0 & 150 & & Low & Medium & High \\
\hline Fra & $3084 \pm 843^{b}$ & $3745 \pm 100^{\mathrm{b}}$ & $4795 \pm 236^{\mathrm{ab}}$ & $3847 \pm 636^{\mathrm{b}}$ & $5075 \pm 493^{\mathrm{a}}$ & $3036 \pm 563^{b}$ \\
\hline Har & $4803 \pm 1232^{\mathrm{ab}}$ & $4544 \pm 45.3^{\mathrm{b}}$ & $5525 \pm 106^{\mathrm{ab}}$ & $4584 \pm 210^{\mathrm{b}}$ & $6179 \pm 538^{a}$ & $4722 \pm 582^{\mathrm{ab}}$ \\
\hline Spr & $0.25 \pm 0.05^{\mathrm{b}}$ & $0.24 \pm 0.01^{\mathrm{b}}$ & $0.30 \pm 0.01^{\mathrm{ab}}$ & $0.25 \pm 0.01^{\mathrm{b}}$ & $0.31 \pm 0.03^{\mathrm{a}}$ & $0.25 \pm 0.03^{b}$ \\
\hline Gum & $880 \pm 84.2^{\mathrm{b}}$ & $779 \pm 82.7^{b}$ & $965 \pm 12.7^{\mathrm{b}}$ & $751 \pm 64.3^{\mathrm{b}}$ & $1299 \pm 135^{\mathrm{a}}$ & $949 \pm 32.5^{\mathrm{b}}$ \\
\hline Che & $224 \pm 65.8^{\mathrm{b}}$ & $191 \pm 27.6^{b}$ & $288 \pm 21.2^{\mathrm{b}}$ & $189 \pm 26.9^{\mathrm{b}}$ & $415 \pm 54.0^{\mathrm{a}}$ & $234 \pm 41.0^{\mathrm{b}}$ \\
\hline Coh & $0.19 \pm 0.02^{\mathrm{b}}$ & $0.17 \pm 0.01^{\mathrm{b}}$ & $0.19 \pm 0.00^{\mathrm{ab}}$ & $0.17 \pm 0.00^{\mathrm{b}}$ & $0.27 \pm 0.07^{\mathrm{a}}$ & $0.21 \pm 0.02^{\mathrm{ab}}$ \\
\hline
\end{tabular}

${ }_{\mathrm{a}, \mathrm{b}}$ Mean with same row having same superscript are not different $(p>0.05)$.

$\mathrm{Pa}^{1)}$, Parameters; Fra, fracturability (g); Har, hardness (g); Spr, springiness (cm); Gum, gumminess; Che, chewiness; Coh, cohesiveness.

Table 3. Microbial counts (log cfu/g) of low-fat functional sausages as affected by sodium lactate and various molecular weights of chitosans during storage time

\begin{tabular}{|c|c|c|c|c|c|c|c|c|c|c|c|c|}
\hline \multirow{2}{*}{ Parameters } & \multicolumn{2}{|c|}{ Nitrite (ppm) } & \multirow{2}{*}{$\begin{array}{l}\text { SL } \\
2 \%\end{array}$} & \multicolumn{3}{|c|}{ Chitosan } & \multicolumn{6}{|c|}{ Storage time (days) } \\
\hline & 0 & 150 & & Low & Med & High & 0 & 3 & 6 & 9 & 12 & 15 \\
\hline L. monocytogenes & 5.98 & 6.04 & 5.11 & 5.70 & 5.28 & 5.51 & $3.01^{\mathrm{f}}$ & $3.74^{\mathrm{e}}$ & $5.48^{\mathrm{d}}$ & $6.70^{c}$ & $7.14^{\mathrm{b}}$ & $7.86^{\mathrm{a}}$ \\
\hline E. coli $\mathrm{O} 157: \mathrm{H} 7$ & $5.54^{\mathrm{a}}$ & $5.63^{\mathrm{a}}$ & $4.42^{\mathrm{b}}$ & $5.35^{\mathrm{a}}$ & $5.00^{\mathrm{ab}}$ & $5.15^{\mathrm{ab}}$ & $3.61^{\mathrm{d}}$ & $4.03^{\mathrm{d}}$ & $4.83^{\mathrm{c}}$ & $5.81^{\mathrm{b}}$ & $6.27^{\mathrm{ab}}$ & $6.52^{\mathrm{a}}$ \\
\hline
\end{tabular}

${ }^{\mathrm{a}-\mathrm{f}}$ Mean with same row having same superscript are not different $(p>0.05)$

the lower water-holding capacity, as compared to the others (Table 1).

\section{Microbial changes of low-fat sausages as affected} by SL and chitosan combinations and storage time

Table 3 shows the microbial changes for E. coli O157:H7 and L. monocytogenes of LFSs as affected by treatment and storage time. Microbial counts of E. coli O157:H7 reduced with the addition of SL alone, however, SL in combined with various MWs of chitosans did not significantly inhibit the microbial growth of $E$. coli O157:H7 (Table 3). These results indicated that the combination of SL and various MW of chitosan did not have a synergistic effect that would inhibit microbial growth, especially at the storage temperature at $10^{\circ} \mathrm{C}$. Sagdic et al. (2002) tested the seven spices for antimicrobial activities and reported that E. coli $\mathrm{O} 157: \mathrm{H} 7$ was inhibited by the use of spice extract in the field of food preservation. They also reported that a 1-3 Log cycle reduction of total viable yeast, mold, and lactic acid bacterial counts in both skinless and standard sausages which had been dipped in $1 \%$ chitosan solution were observed at $7^{\circ} \mathrm{C}$ of storage. However, no differences in microbial counts between treated and untreated samples were observed ( $p>0.05)$. Thus, the antimicrobial activity of SL and chitosan combination might be dependent upon the storage temperature. Although no statistical differences were observed, the addition of low MW of chitosan reduced the antilisterial effect in LFSs and only a 1-1.5 log cycle reduction was observed between control and treated samples (Figs. 2, 3). In this case, the low MW of chitosan may not inhibit, but accelerate the microbial growth of L. monocytogenes. Thus, microbial counts of $L$. monocytogenes were not significantly affected by the addition of SL and chitosans at the storage temperature of $10^{\circ} \mathrm{C}$. In our previous report, $3.3 \% \mathrm{SL}$ retarded the

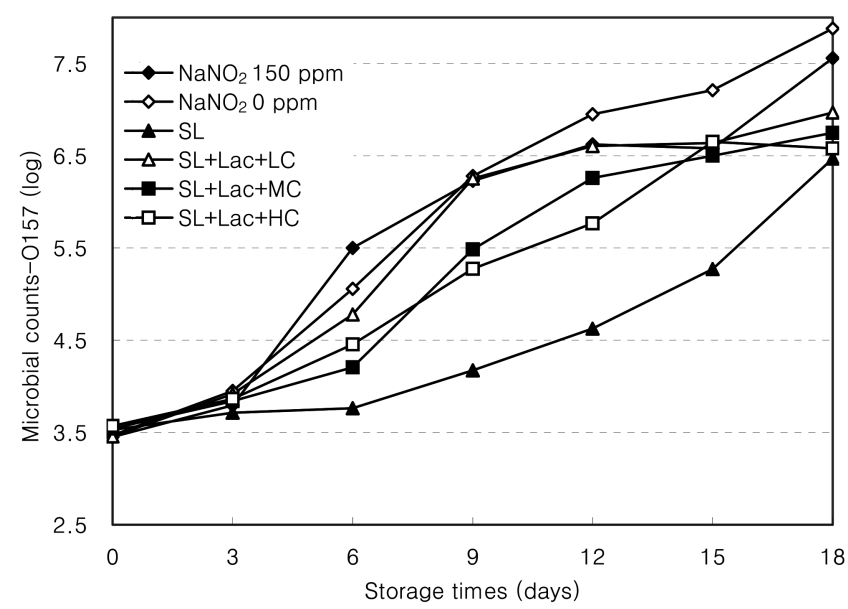

Fig. 2. Changes of bacterial counts for E. coli 0157 of low-fat functional sausages made with sodium lactate and various molecular weights of chitosans during storage at $1^{\circ} \mathrm{C} . \mathrm{SL}$, sodium lactate; $\mathrm{SL}+\mathrm{Lac}+\mathrm{LC}$, chitosan with low molecular weight $(1.5 \mathrm{kDa})$; SL+Lac+MC, chitosan with medium molecular weight $(30-50 \mathrm{kDa})$; SL+Lac+ $\mathrm{Hc}$, chitosan with high molecular weight (200 kDa). 


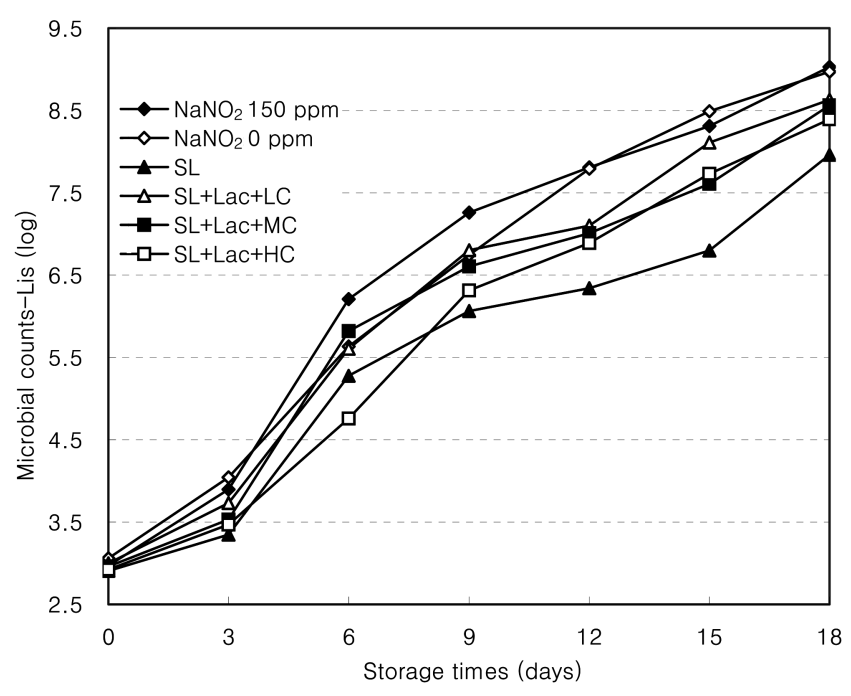

Fig. 3. Changes of bacterial counts for Listeria monocytogenes of low-fat functional sausages made with sodium lactate and various molecular weights of chitosans during storage at $1^{\circ} \mathrm{C}$. SL, sodium lactate; SL+Lac $+\mathrm{LC}$, chitosan with low molecular weight $(1.5 \mathrm{kDa})$; SL+Lac+MC, chitosan with medium molecular weight (30-50 kDa); SL+Lac+Hc, chitosan with high molecular weight $(200 \mathrm{kDa})$.

growth of L. monocytogenes at the storage temperature of $4^{\circ} \mathrm{C}$ (Choi et al., 2003). Thus, microbial retardation may be changed due to the different storage temperatures. In our study, the addition of SL alone reduced the 1-2 log cycle reduction at 15 days of storage at $10^{\circ} \mathrm{C}$. Our results indicated that the addition of SL and chitosans still extended the shelf-life of LFS approximately 3-6 days at $10^{\circ} \mathrm{C}$ before reaching the maximum acceptable level $\left(10^{7}\right.$ cfu/g) (Figs. 2, 3), however it may not be strong enough to have antimicrobial activity as SL alone does. Sagoo et al. (2002) reported that treatments with chitosans increased the shelf-life of LFSs from 7 to 15 days at a chilled temperature. Based on our results, the storage temperature would be critical for the extension of shelf-life of LFSs and should be as low as possible to have a maximum antimicrobial activity, thus, most mesophilic bacteria would not grow well at such a low temperature (Chin and Choi, 2005).

\section{Acknowledgements}

This study was supported by a grant of the Korea Health 21 R\&D Project, Ministry of health\& Welfare, Republic of Korea (01-PJ1-PG3-22000-0062). In addition, this was partially supported by Biotechnology Research Institute, Chonnam National University, Gwangju, Korea.

\section{References}

1. American heat association (AHA) (1978) Diet and coronary heat disease. Circul. 58(4), 762A-766A.

2. AOAC. (1995) Official Methods of Analysis. 16th edition. AOAC International, Washington, DC.

3. Bloukas, J. G., Arvanitoyannis I, S., and Siopi, A. A. (1997) Effect of natural colorants and nitrites on color attribute of frankfurters. Meat Sci. 52, 257-265.

4. Bourne, M. C. (1978) Texture profile analysis. Food Technol.32(7), 62-66, 72.

5. Byun, M. W., Lee, J. W., Yook, H. S., Lee, K. H., and Kim, K. Y. (1999) The improvement of color and shelf-life of ham by gamma irradiation. J. Food Prot. 62, 1162-1166.

6. Chin, K. B. and Choi, S. H. (2001) Evaluation of the addition of sodium lactate and a fat replacer in very low fat bologna (model system) on the product quality and shelf-life effect during refrigerated storage. J. Korean Soc. Food Sci. Nutr. 30(5), 858-864.

7. Chin, K. B. and Choi, S. H. (2005) Evaluation of sodium lactate in combined with various molecular weights of chitosans and laccaic acid for the improvement of shelf-life and color of low-fat sausage during refrigerated storage. Food Sci. Biotechnol. 14(2), 275-279.

8. Chin, K. B., Lee, H. L., Kook, S. H., Yoo, S. S., and Chun, S. S. (2004) Evaluation of various combinations of pork lean and water added on the physicochemical, textural and sensory characteristics of low-fat sausages. Food Sci. Biotechnol. 13(4), 481-484.

9. Chin, K. B., Kim, K. H., and Lee, H. C. (2006) Physicochemical and textural properties, and microbial counts of meat products sold at Korean markets. Korean J. Food Sci. Ani. Resour. 26(1), 98-105.

10. Chin, K. B., and Wang, S. H. (2004) Product quality of lowfat sausages formulated with two levels of chitosan. Korean J. Food Sci. Ani. Resour. 24(4), 361-366.

11. Choi, S. H, and Chin, K. B. (2002) Development of low-fat comminuted sausage manufactured with various fat replacers similar textural characteristics to those with regular-fat counterpart. Korean J. Food Sci. Technol. 34(4), 577-582.

12. Choi, S. H. and Chin, K. B. (2003) Evaluation of sodium lactate as a replacement for conventional chemical preservatives in comminuted sausages inoculated with Listeria monocytogenes. Meat Sci. 65, 531-537.

13. Choi, S. H, Kim, K. H, Eun, J. B., and Chin, K. B. (2003) Growth suppression of inoculated Listeria monocytogenes and physicochemical ands textural properties of low-fat sausages as affected by sodium lactate and a fat replacer. J. Food Sci. 68(8), 2542-2546.

14. Jauregui, C. A., Regenstein, J. N., and Baker, R. C. (1981) A simple centrifugal method for measuring expressible moisture, a water-binding property of muscle foods. J. Food Sci. 46, 271-273.

15. Jo, C., Lee, J. W., Lee, K. H., Lee, J. H., and Byun, M. W. (2001a) Quality properties of pork sausage prepared with water-soluble chitosan oligomer. Meat Sci. 59, 369-375. 
16. Jo, C., Lee, J. W., Lee, K. H., Lee, J. H., and Byun, M. W. (2001b) Effect of irradiation on $\mathrm{pH}$, color, and sensory quality of cooked pork sausage with added chitosan oligomer. $J$. Food Sci. Nutr. 6(3), 147-151.

17. Keeton, J. T. (1994) Low-fat meat products - Technological problems with processing. Meat Sci. 36, 261-276.

18. Kook, S. H., Choi, S. H, Kang, S. M., Park, S. Y., and Chin, K. B. (2003) Product quality and extension of shelf-life of low-fat functional sausages manufactured with sodium lactate and chitosans during refrigerated storage. Korean $J$. Food Sci. Ani. Resour. 23(2), 128-136.

19. Lin K.W., and Chao, J. Y. (2001) Quality characteristics of reduced fat Chinese-style sausage as related to chitosan's molecular weight . Meat Sci. 59, 343-351.

20. Lin, K. W. and Lin, S. N. (2002) Effects of sodium lactate and trisodium phosphate on the physicochemical properties and shelf life of low-fat Chinese-style sausage. Meat Sci. 60, 147-154.

21. Matulis, R. J., Mckeith, F. K., Sutherland, J. W., and Brewer, M. S. (1995a) Sensory characteristics of frankfurters as affected by fat, salt and pH. J. Food Sci. 60, 42-47.

22. Matulis, R. J., Mckeith, F. K., Sutherland, J. W., and Brewer, M. S. (1995b) Sensory characteristics of frankfurters as affected by salt, fat, soy protein, and carrageenan. J. Food Sci. 60, 48-54.

23. Murano, E. A. and Rust, R. E. (1995) General microbial pro- file of low-fat frankfurters formulated with sodium lactate and a texture modifier. J. Muscle Foods 18, 313-323.

24. Park, S. M., Youn, S.K., Kim, H. J., and Ahn, D. H. (1999) Studies on the improvement of storage property in meat sausage using chitosan-I. J Korean Soc. Food Sci. Nutr. 28(1), 167-171.

25. Roller, S., Sagoo, S., Board, R., O'Mahony, T., Caplice, E, Fitzgerald, G., Fogden, M., Owen, M., and Fletcher, H. (2002) Novel combinations of chitosan, carnocin and sulphite for the preservation of chilled pork sausages. Meat Sci. 62,165-177.

26. Sagdic, O., Kuscu, A., Ozcan, M., and Ozcelik, S. (2002) Effect of Turkish spice extracts at various concentrations on the growth of Escheria coli O157:H7. Food Microbiol. 19, 473-480.

27. Sagoo, S., Board, R., and Roller, S. (2002) Chitosan inhibits growth of spoilage microorganisms in chilled pork products. Food Microbiol. 19, 175-182.

28. SAS Institute Inc. (1989) SAS User's Guide; Statistical Analysis System, Cary. NC.

29. Youn, S. K., Park, S. M., and Ahn, D. H. (2000) Studies on the improvement of storage property in meat sausage using chitosan-II. Difference of storage property by molecular weight of chitosan. J. Korean Soc. Food Sci. Nutr. 29(5), 849-853.

(Received 2008.7.8/Revised 2009.1.7/Accepted 2009.1.20) 